\title{
Efficiency of Genetic Transformation via Pollen-Tube Pathway of Jatropha (Jatropha curcas L.) Based on Histochemical and Molecular Analysis
}

\author{
Efisiensi Transformasi Genetik Tanaman Jarak Pagar (Jatropha curcas L.) \\ melalui Jalur Tabung Polen Berdasarkan Analisis Histokimia dan Molekuler
}

\author{
Agus Zainudin ${ }^{1,2}$, Bambang Sapta Purwoko ${ }^{3 *}$, Tri Joko Santoso ${ }^{4}$, Sintho Wahyuning Ardie ${ }^{3}$, and \\ Trikoesoemaningtyas ${ }^{3}$
}

\begin{abstract}
${ }^{1}$ Plant Breeding and Biotechnology Study Program, School of Graduate Studies, Bogor Agricultural University
${ }^{2}$ Departement of Agronomy, Faculty of Agriculture and Animal Husbandry

University of Muhammadiyah Malang, Jl Raya Tlogomas No 246, Malang 65144, Indonesia

${ }^{3}$ Departement of Agronomy and Horticulture, Faculty of Agriculture, Bogor Agricultural University

J1. Meranti, Kampus IPB Darmaga, Bogor 16680, Indonesia

${ }^{4}$ Center for Agricultural Biotechnology and Genetic Resources Research and Development (ICABIOGRAD)

Jl. Tentara Pelajar No. 3A, Bogor 16111, Indonesia
\end{abstract}

Received 22 September 2016/Accepted 15 March 2017

\begin{abstract}
The genetic transformation via pollen-tube pathway is an alternative method to overcome the constraints imposed by genotype specificity in transformation and regeneration in jatropha (Jatropha curcas L.) tissue culture. Therefore, it is necessary to establish important parameters for efficient genetic transformation of jatropha via pollen-tube pathway. The objective of the research was to study the efficiency of direct transformation of jatropha via pollen-tube pathway based on histochemical and molecular analysis. Solution of purified pCAMBIA1301 DNA plasmid carrying a hptII marker gene and a gus reporter gene with concentration level of 0.05, 0.25, $0.50 \mu \mathrm{g} \mu \mathrm{l}^{-1}$ were applied to stigma of flowers at 1, 2, 4, 7, $10 \mathrm{~h}$ after pollination. Seedling of IP3A, IP3P and JcUMM18 jatropha's genotypes derived from 15 combination treatments of plasmid DNA concentration and application time, also wild type was subjected to histochemical and molecular analyses. Based on those analyses, the efficiency of transformation via pollen-tube pathway of three jatropha genotypes ranged from 1.5-16.7\%. PCR analysis showed that a number of positive plants were identified by using specific primers hptII and gus, i.e. 1-3 and 3-7 plants of the 15 combined treatments, respectively. It indicated that the transformation efficiency via the pollen-tube pathway varied in each jatropha genotype.
\end{abstract}

Keywords: Jatropha curcas L., pCAMBIA1301, plasmid DNA, stigma-drip

\section{ABSTRAK}

Transformasi genetik melalui jalur tabung polen adalah metode alternatif untuk mengatasi kendala transformasi dan regenerasi dalam kultur jaringan yang terjadi pada genotipe tertentu tanaman jarak pagar. Oleh karena itu, perlu dilakukan evaluasi parameter-parameter penting untuk transformasi genetik jarak pagar melalui jalur tabung polen yang efisien. Tujuan dari penelitian ini adalah untuk mempelajari efisiensi transformasi langsung dari pohon jarak melalui jalur pollentube berdasarkan analisis histokimia dan molekuler. DNA plasmid pCAMBIA1301 murni yang membawa gen marka hptII dan gen pelapor gus dengan tingkat konsentrasi 0,05, 0,25, 0,50 $\mu \mathrm{g} \mu \mathrm{l}^{-1}$ diteteskan pada stigma bunga pada 1, 2, 4, 7, 10 jam setelah polinasi. Kecambah generasi T0 jarak pagar genotipe IP3A, IP3P dan JcUMM18 yang diperoleh dari 15 kombinasi perlakuan dan kontrol (tipe liar) digunakan untuk uji secara histokimia dan analisis molekuler. Berdasarkan hasil analisis, efisiensi transformasi melalui jalur tabung polen dari tiga genotipe jarak pagar berkisar antara 1.5-16.7\%. Berdasarkan analisis PCR dengan primer spesifik hptII dan gus, tanaman transgenik diperoleh pada 1-3 dan 3-7 dari 15 kombinasi perlakuan konsentrasi dengan waktu penetesan DNA plasmid. Hal ini mengindikasikan bahwa efisiensi transformasi melalui jalur tabung polen berbeda-beda pada masing-masing genotipe jarak pagar.

Kata kunci: Jatropha curcas L., pCAMBIA1301, plasmid DNA, tetes stigma

\footnotetext{
* Corresponding author. e-mail: bspurwoko@ipb.ac.id
} 


\section{INTRODUCTION}

Jatropha (Jatropha curcas L., Euphorbiaceae) is a perennial, non-food oilseed and potential biodiesel crop that can be cultivated on marginal land (Costa et al., 2010; Madhaiyan et al., 2015). Yield variety of jatropha is one of the factor that cause the gap between the potential and actual yields (Djumali and Nurnasari, 2014). Unlike palm oil, soybean, maize, sunflower and other oil crops, there is no widely cultivated improved jatropha varieties. Development of Jatropha, an important tropical biofuel crop, to coastal sandy soil is an urgent situation due to more limited of fossil fuel in one side, and high potency of coastal sandy land that has not been utilized yet (Parwata et al., 2014).

Genetic engineering is a promising and feasible way to dramatically improve plant traits, i.e. resistance to plant disease or pest, tolerance to abiotic stress etc. However, application of genetic engineering technique for jatropha breeding is relatively new. Because of the lack of efficient regeneration and transformation procedures, jatropha remains a difficult plant for genetic transformation. Thus, the efficient transformation method for this plant is not fully established yet. One major strategy for producing transgenic jatropha is to improve transformation efficiency (Tsuchimoto et al., 2012). Initial transformation experiments of jatropha were conducted by using Agrobacterium mediatied. Unfortunately, this procedure produces extremely low transformation efficiency. The step of root induction is also challenging because the resultant rate is usually low (Khemkladngoen et al., 2011a,b).

One of the alternative methods to generate transgenic plants in several recalcitrant species is transformation via pollen-tube pathway. This method is used to transfer foreign genes or DNA into zygotic embryos through pollen-tube pathway and then inserting into plant genome (Keshamma et al., 2008; Wang et al., 2013). Pollen tube pathwaymediated transformation is a tissue culture or genotype independent transformation method and also it does not require expensive instrument (Wang et al., 2013). Method of genetic transformation via pollen-tube pathway has been successfully carried out at several plants (Zhang et al., 2012; Wang et al., 2013), but the application of such methods in jatropha has not been reported yet. This research was aimed to assess the efficiency of direct transformation of jatropha via pollen-tube pathway used plasmid pCAMBIA1301 based on histochemical and molecular analysis.

\section{MATERIALS AND METHODS}

This research was conducted in November 2014 until January 2016 at green house and molecular biology laboratory of Center for Agricultural Biotechnology and Genetic Resources Research and Development, Bogor, and at Center for Biotechnology Development, University of Muhammadiyah Malang.

Plasmid pCAMBIA1301 carrying a hptII marker gene and a gus reporter gene were used in this study. T0 generation plants (the parent transformed plants) of IP3A,
IP3P and JcUMM18 genotype derived from 15 treatments of direct transformed via pollen-tube pathway (combination of three concentration level of pCAMBIA1301: 0.05, 0.25, $0.50 \mu \mathrm{g} \mu \mathrm{L}^{-1}$; and five time level of stigma-drip: $1,2,4$, $7,10 \mathrm{~h}$ after pollination) and wild type of each genotipe of jatropha seedlings were subjected to histochemical and molecular analysis. The arrangement of treatments was a randomized complete block design with three replicates. All of seedling that grew well at each treatment was used as a sample.

\section{Hygromycin Resistant Assay}

The hygromycin resistant $\mathrm{T} 0$ putative transgenic plants were identified by brush-painting method (Bibi et al., 2013, modified). The leaf surface of putative transgenic plant was painted with 10 and $20 \mu 1 \mathrm{~mL}^{-1}$ hygromycin solution (from Hygromycin B solution, $50 \mathrm{mg} \mathrm{mL}^{-1}$, Roche Diagnostics Gmbh) by a small brush and marked with a marker pen to identify brushed leaves with hygromycin solution. The painting was conducted at afternoon. The leaves were scored for hygromycin resistant 48 hours after application. No necrotic symptoms was observed in hygromycin resistant plant. Number of necrosis free plants divided by total number of plants was counted as percentage of hygromycin resistant plants.

\section{Histochemical GUS (-glucuronidase) Assay}

GUS assay was done by incubating the leaf tissues in freshly prepared GUS assay buffer $\left(1 \mathrm{~g} \mathrm{~L}^{-1} \mathrm{X}\right.$-Gluc with $0.05 \mathrm{M} \mathrm{Na} \mathrm{HPO}_{4}, 0.5 \mathrm{mMK}_{3} \mathrm{Fe}(\mathrm{CN}), 0.5 \mathrm{mM} \mathrm{K} \mathrm{K}_{4} \mathrm{Fe}(\mathrm{CN})$, $10 \mathrm{mM}$ EDTA and $0.1 \%(\mathrm{v} / \mathrm{v})$ Triton $\mathrm{X}-100)$ for $12 \mathrm{~h}$ at 37 ${ }^{\circ} \mathrm{C}$. Thereafter, the tissues were destained with $70 \%$ alcohol to examine and count blue spots. Individual plant with at least one discrete blue region on the leaf were scored as GUS positive (Jefferson, 1987). Number of blue spot plants divided by total number of plants was counted as percentage of positive plants contained gen gus.

\section{PCR Analysis}

Total genomic DNA of T0 putative transgenic plants were isolated by using modified CTAB method (Dhakshanamoorthy and Selvaraj, 2009). Specific primers for hptII (forward 5'-GATGCCTCCGCTCGAAGTAGCG3' and reverse 5'-GCATCTCCCGCCGTGCAC-3') and gus gene (forward 5'-AACTGGACAAGGCACTACCGG-3' and reverse 5'-GTATCGGTGTGAGCGTCGCAGAAC-3') were used for PCR analysis.. The amplification program for the hptII gene was as follows: $94{ }^{\circ} \mathrm{C}$ for 1 minute for initial denaturation, then 40 cycles at $94{ }^{\circ} \mathrm{C}$ for 1 minute for denaturation, $58{ }^{\circ} \mathrm{C}$ for 1 minute for primer annealing, and $72{ }^{\circ} \mathrm{C}$ for $1 \mathrm{~min}$ for extension, followed by a final extention at $72{ }^{\circ} \mathrm{C}$ for 5 minutes. For the gus gene, the PCR cycle was as follows: $94{ }^{\circ} \mathrm{C}$ for 1 minute for initial denaturation, then 40 cycles at $94{ }^{\circ} \mathrm{C}$ for 1 minute for denaturation, $48{ }^{\circ} \mathrm{C}$ for 1 minute for primer annealing, and $72{ }^{\circ} \mathrm{C}$ for 1 
min for extension, followed by a final extention at $72{ }^{\circ} \mathrm{C}$ for 5 minutes. The amplified product were separated in a $1 \%$ agarose gel and stained with $10 \mathrm{mg} \mathrm{L}^{-1}$ ethidium bromide and visualized under UV gel doc.

\section{Data Analysis}

Histochemical and molecular data were subjected to one-way analysis of variance at $5 \%$ and $1 \%$ level. Before analysis, data would be transformed by $\sqrt{ }(x+0.5)$. Duncan's multiple range test at 5\% level of significance was used to separate differences between mean of treatments.

\section{RESULTS AND DISCUSSION}

\section{Hygromycin Resistant Assay}

Hygromycin has been used for the screening of hygromycin resistant plants in various crops (Kumar et al., 2013). Selection conditions were optimized for hygromycin resistance in many crops using leaf tip assay method (Noor et al., 2000). To minimize the use of hygromycin, this research applied a brush-painting method to screen hygromycin resistant plants with two concentration level of hygromycin, i.e. 10 and $20 \mu \mathrm{mL}^{-1}$. Results demonstrated

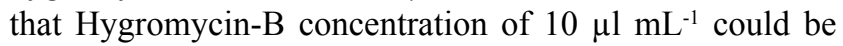
used to select transgenic plant of jatropha, on the contrary, most of plants that were treated by concentration of $20 \mu \mathrm{l}$ $\mathrm{mL}^{-1}$ experienced necrosis symptoms (Figure 1). Bibi et al. (2013) used range of hygromycin (25-200 $\left.\mathrm{mg} \mathrm{L}^{-1}\right)$ on cotton leaves at different growth stages. The plants showed healthy and green leaf after treatment (no necrotic symptoms) are considered as transgenic plants.

Results also indicated that necrosis free plants were obtained in almost DNA plasmid concentration and time of stigma-drip treatments in IP3A and IP3P genotype, except combined treatment of $0.05 \mu \mathrm{g} \mu \mathrm{L}^{-1}$ and $2 \mathrm{~h}$ after pollination, $0.25 \mu \mathrm{g} \mu \mathrm{L}^{-1}$ and $7 \mathrm{~h}$ after pollination, $0.5 \mu \mathrm{g}$ $\mu \mathrm{L}^{-1}$ and $7 \mathrm{~h}$ after pollination. In JcUMM18 genotipe, only three combined treatment had necrosis free plants. There were no significant effect of all treatments on percentage of necrosis free plants in each genotipe (Table 1). Percentage of hygromycin tolerance plant of IP3A, IP3P and JcUMM18 genotype range from $1.5-16.7 \%$. Kumar et al. (2010) reported that leaf explants of jaropha that had been infected and co- cultivated with Agrobacterium, resulted in 3-4 shoots per explant and $20-30 \%$ responded positively to hygromycin containing medium. One advantage of use of the brush painting method is not costly and laborious when many plants are used in a hygromycin resistant analysis. However, the method is sometimes affected by environmental or plant conditions. Plant leaves exhibited differential sensitivity to hygromycin application under certain field conditions. The possible reason for this differential sensitivity might be leaf age, young leaves from top canopy being more sensitive to hygromycin application. In field, due to fluctuation in climatic conditions, sometimes low concentration of hygromycin is not affective (Bibi et al., 2013).

\section{Histochemical GUS Reporter Assay}

Histochemical analysis of GUS activity was carried out with putative hygromycin-resistant transgenic lines to confirm the transformation events. GUS expression was examined in leaves of putative transgenic plants. GUS-positive blue coloration was visibly detected in all transgenic tissues stained with X-gluc solution, whereas no blue color was observed in the non-transformed tissues (Kumar et al., 2010). Results of this research demonstrated that plants with blue spots were obtained in almost DNA plasmid concentration and time of stigma-drip treatments in IP3A and IP3P genotype same as result of hygromycin resistant assay, also in JcUMM18 genotipe. However, there were no significant effect of all treatments on percentage of GUS positive plants in each of three genotypes (Table 1). Percentage of GUS positive plant of IP3A, IP3P and JcUMM18 genotype ranged from 1.5-16.7\%. Histochemical staining activity of glucuronidase in transgenic leaves of jatropha was shown in Figure 2. Leaves of putatively transgenic plants indicated blue color or blue spot, conversely no blue spot in non transgenic plant.

\section{Molecular Analysis of hptII and gus Gene}

To further confirm putative transgenic plants at a molecular level, PCR analysis was conducted on the hptII and gus genes that were integrated in the genomic DNA of these plant with hygromycin resistance. A DNA band was detected at a size of $500 \mathrm{bp}$ and $1,000 \mathrm{bp}$ in the transgenic lines by genomic PCR with primers specific for hptII
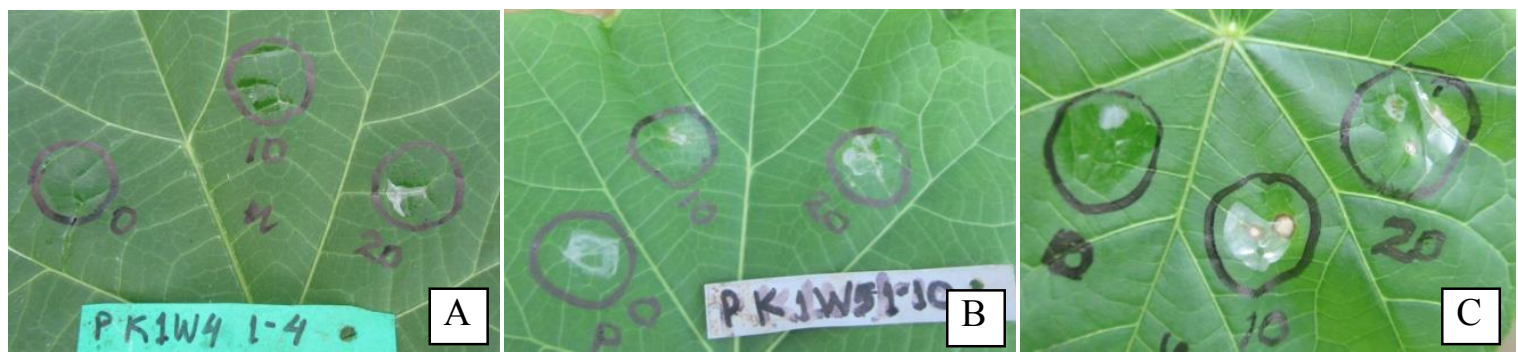

Figure 1. No necrotic in transgenic (A) and necrotic patches in non transgenic (B) and wild type (C) produced after application of hygromycin on leaves using leaf painting method 
Table 1. Number of seedling, necrosis free plants and GUS stained plus plants of T0 generation of three jatropha genotypes in combination of concentration and application time of plasmid DNA

\begin{tabular}{lccccccccc}
\hline \multirow{2}{*}{ Treatments } & \multicolumn{3}{c}{ Number of seedling } & \multicolumn{3}{c}{ Necrosis free plants (\%) } & \multicolumn{3}{c}{ GUS stained + plants (\%) } \\
\cline { 2 - 9 } Control & IP3A & IP3P & JcUMM18 & IP3A & IP3P & JcUMM18 & IP3A & IP3P & JcUMM18 \\
K1W1 & 11.3 & 8.7 & 13.7 & 0.0 & 0.0 & 0.0 & 0.0 & 0.0 & 0.0 \\
K1W2 & 9.3 & 11.3 & 14.3 & 4.4 & 6.4 & 0.0 & 4.4 & 6.4 & 0.0 \\
K1W3 & 7.3 & 12.0 & 9.7 & 0.0 & 0.0 & 0.0 & 0.0 & 0.0 & 0.0 \\
K1W4 & 15.0 & 9.0 & 7.0 & 0.0 & 4.4 & 5.6 & 0.0 & 4.4 & 5.6 \\
K1W5 & 10.3 & 14.7 & 9.7 & 7.8 & 2.1 & 0.0 & 7.8 & 2.1 & 0.0 \\
K2W1 & 15.0 & 11.3 & 9.3 & 3.9 & 6.7 & 0.0 & 3.9 & 6.7 & 0.0 \\
K2W2 & 12.0 & 9.3 & 10.0 & 0.0 & 0.0 & 0.0 & 0.0 & 0.0 & 0.0 \\
K2W3 & 10.7 & 10.3 & 15.3 & 0.0 & 2.1 & 1.7 & 0.0 & 2.1 & 1.7 \\
K2W4 & 10.3 & 7.7 & 11.3 & 0.0 & 11.1 & 0.0 & 0.0 & 11.1 & 0.0 \\
K2W5 & 15.7 & 13.3 & 13.3 & 0.0 & 0.0 & 0.0 & 0.0 & 0.0 & 0.0 \\
K3W1 & 13.3 & 11.3 & 10.0 & 16.7 & 1.5 & 3.7 & 16.7 & 1.5 & 3.7 \\
K3W2 & 12.3 & 12.7 & 13.7 & 6.7 & 2.4 & 0.0 & 6.7 & 2.4 & 0.0 \\
K3W3 & 12.3 & 17.3 & 14.3 & 3.3 & 0.0 & 0.0 & 3.3 & 0.0 & 0.0 \\
K3W4 & 10.3 & 12.3 & 9.7 & 5.4 & 0.0 & 0.0 & 5.4 & 0.0 & 0.0 \\
K3W5 & 5.7 & 17.0 & 7.0 & 0.0 & 0.0 & 0.0 & 0.0 & 0.0 & 0.0 \\
& 11.3 & 9.3 & 9.7 & 5.6 & 0.0 & 0.0 & 5.6 & 0.0 & 0.0 \\
\hline
\end{tabular}

Remarks: control $=$ wild type, $\mathrm{K} 1=$ concentration of $0.05 \mu \mathrm{g} \mu \mathrm{L}^{-1}, \mathrm{~K} 2=0.25 \mu \mathrm{g} \mu \mathrm{L}^{-1}, \mathrm{~K} 3=0.50 \mu \mathrm{g} \mu \mathrm{L}^{-1}$ pCAMBIA1301, W1 = stigma-drip at $1 \mathrm{~h}, \mathrm{~W} 2=2 \mathrm{~h}, \mathrm{~W} 3=4 \mathrm{~h}, \mathrm{~W} 4=7 \mathrm{~h}, \mathrm{~W} 5=10 \mathrm{~h}$ after pollination, $\mathrm{ns}=$ non significant at $\alpha=0.05$

and gus respectively, while this band was not detected in non-transformed plants (Figure 3-4). The percentage of individual plants that indicated hptII gene in transgenic plants is less than gus gene in three genotypes tested. Statistically, it indicated that insertion of hptII and gus gene was not significantly different in the combination treatment

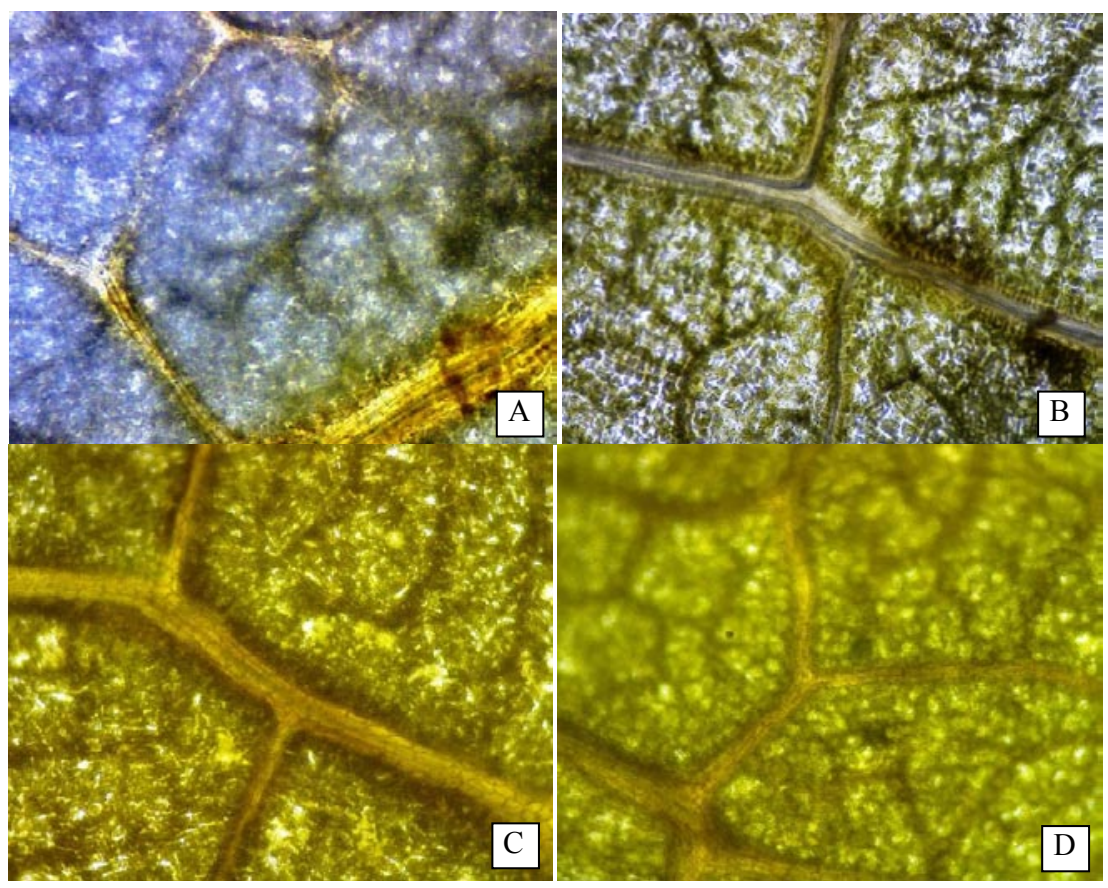

Figure 2. Histochemical staining showing activity of glucuronidase in transgenic leaves with blue spot (A \& B); and no activity of glucuronidase in non transgenic (C) and wild type leaves (D) 


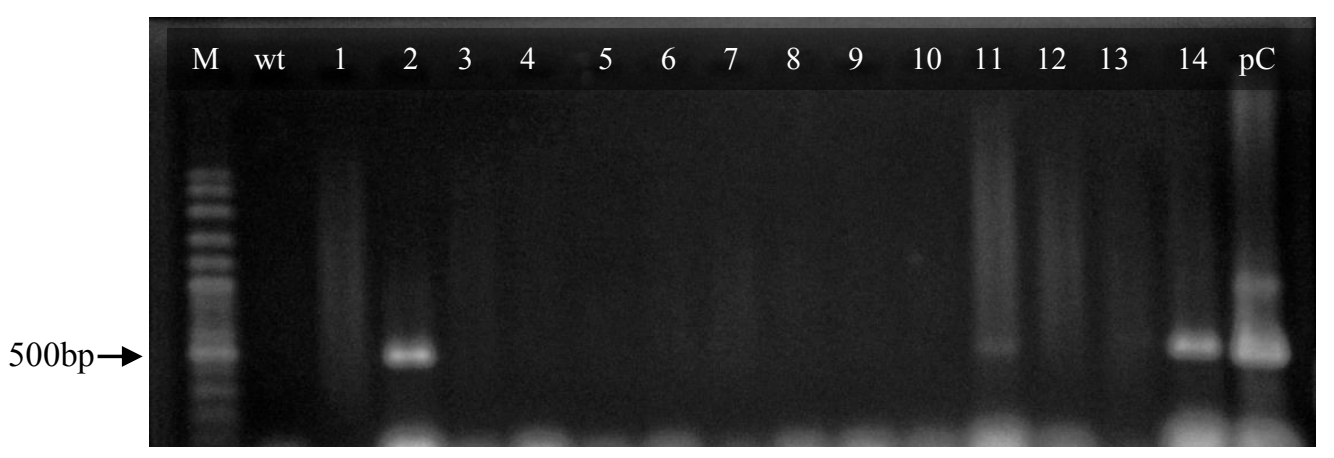

Figure 3. PCR amplification of the hptII gene (500 bp)

Remarks: $\mathrm{M}=$ marker 100bp; lanes 2, 11, 14 = putative transgenic plants; $\mathrm{pC}=\mathrm{pCAMBIA1301}$ (positive control); wt = wild type

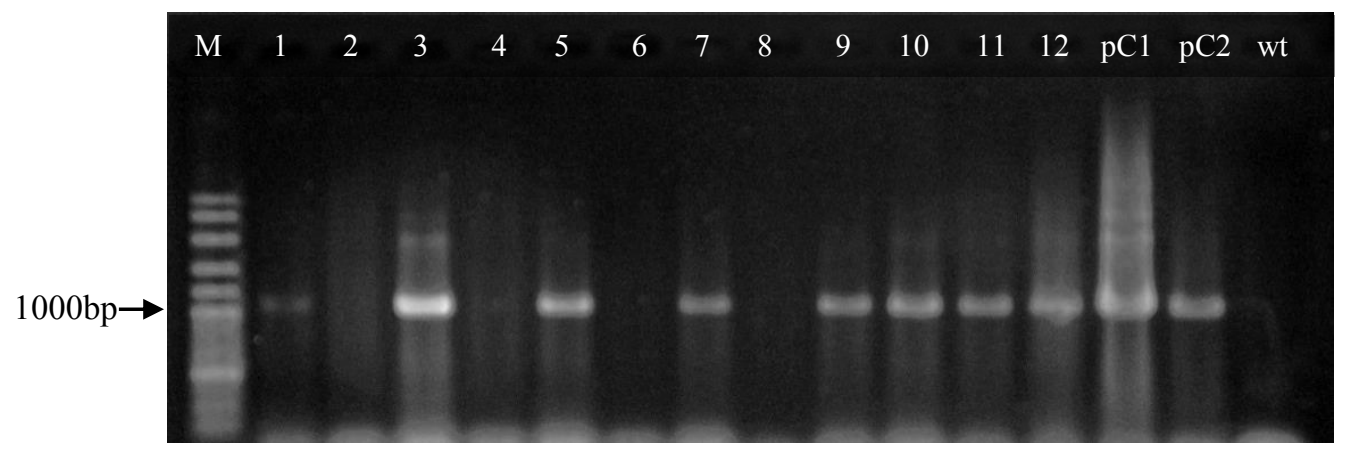

Figure 4. PCR amplification of the gus gene (1,000 bp)

Remarks: $\mathrm{M}=$ marker $100 \mathrm{bp}$, lanes $1,3,5,7,9,10-12=$ putative transgenic plants. $\mathrm{pC}=\mathrm{pCAMBIA1301}($ positive control), wt $=$ wild type

of concentration and time application of plasmid DNA from each jatropha genotypes. The percentage of positive PCR hptII or gus gene in three genotypes of jatropha was equal to the percentage range of hptII and gus gene expression: 1.5$16.7 \%$, but not all individuals expressing hptII and gus gene by histochemical analysis showed product positive result by PCR analysis (Table 2).

Research of jatropha transformation mediated Agrobacterium tumefacient conducted by Li et al. (2008) showed that the transformation efficiency was $13 \%$ based on the detection of b-glucuronidase activity, PCR and Southern hybridization analysis. The calculation of transformation efficiency was obtained from the 100 cotyledon explants produced 13 transgenic plants after approximately 4 months. Gu et al. (2014) produced one marker-free transgenic $J$. curcas line that carries a single copy of the PPepc:Cry1Ab/1Ac:TNos gene mediated by A. tumefacient. Joshi et al. (2011) reported a successful attempt of genetic transformation was made with optimized conditions using particle gene gun and establishing a stable transformation in $J$. curcas with $44.7 \%$ transformation efficiency.

Zhang et al. (2009) reported that the transformation efficiency of cotton transformation via pollen-tube pathway was usually relative low, ranging from $0.5 \%$ to $1 \%$, if calculated from the setting bolls transgenically to the ovaries injected with the exogenous DNA. The low transformation efficiencies may be due to three reasons. Firstly, the DNA quality was not sufficient and the DNA concentration injected was unsuitable. The exogenous DNA without high quality usually was covalently combined with other molecules, such as proteins and polysaccharide, which could slow down the movement of the injected DNA in the pollen tube and decrease the integration rate of the exogenous DNA into the chromosome of the fertilized zygote. Secondly, high molecular weight of DNA for injection resulted in inconvenient transportation via the pollen tube, which could also affect its insertion frequency into the fertilized zygote. Thus, for the genetic transformation via pollen-tube pathway approach, the high quality and suitable length of the exogenous DNA should be considered in advance.

There were reports on cotton genetic transformation showing the transformation frequency to be dependent of genotypes (Wang et al., 2013). Therefore, the pollen-tube transformation pathway approach has an extra advantage of genotype independence, except for its simplicity, and easy manipulation. Putative transgenic plants of three genotipes could be gotten by pollen-tube transformation pathway.

Hao et al. (2011) transformed a marker-free and vectorfree antisense 1-aminocyclopropane-1-carboxylic acid oxidase construct into melon via the pollen-tube pathway (the plasmid DNA solution was dripped onto the surface of the style) and obtained approximately $0.7 \%$ transformation frequency. Shan et al. (2012) succeeded in obtaining antisense AAT transgenic melon plants by injecting plasmid DNA into the pollinated ovary and a transformation rate of approximately $1.3 \%$ was achieved. 
Tabel 2. Percentage of positive PCR hptII and gus of T0 generation of three jatropha genotypes in combination of concentration and application time of plasmid DNA

\begin{tabular}{|c|c|c|c|c|c|c|}
\hline \multirow{2}{*}{ Treatments } & \multicolumn{3}{|c|}{ Positive PCR hptII (\%) } & \multicolumn{3}{|c|}{ Positive PCR gus (\%) } \\
\hline & IP3A & IP3P & JcUMM18 & IP3A & IP3P & JcUMM18 \\
\hline Control & 0.0 & 0.0 & 0.0 & 0.0 & 0.0 & 0.0 \\
\hline K1W1 & 4.4 & 0.0 & 0.0 & 4.4 & 0.0 & 0.0 \\
\hline K1W2 & 0.0 & 0.0 & 0.0 & 0.0 & 0.0 & 0.0 \\
\hline K1W3 & 0.0 & 0.0 & 0.0 & 0.0 & 2.2 & 2.8 \\
\hline K1W4 & 0.0 & 0.0 & 0.0 & 4.8 & 2.1 & 0.0 \\
\hline K1W5 & 0.0 & 0.0 & 0.0 & 2.0 & 2.0 & 0.0 \\
\hline K2W1 & 0.0 & 0.0 & 0.0 & 0.0 & 0.0 & 0.0 \\
\hline K2W2 & 0.0 & 0.0 & 0.0 & 0.0 & 2.1 & 1.7 \\
\hline K2W3 & 0.0 & 11.1 & 0.0 & 0.0 & 11.1 & 0.0 \\
\hline K2W4 & 0.0 & 0.0 & 0.0 & 0.0 & 0.0 & 0.0 \\
\hline K2W5 & 16.7 & 0.0 & 3.7 & 16.7 & 1.5 & 3.7 \\
\hline K3W1 & 0.0 & 2.4 & 0.0 & 6.7 & 2.4 & 0.0 \\
\hline K3W2 & 3.3 & 0.0 & 0.0 & 0.0 & 0.0 & 0.0 \\
\hline K3W3 & 0.0 & 0.0 & 0.0 & 5.4 & 0.0 & 0.0 \\
\hline K3W4 & 0.0 & 0.0 & 0.0 & 0.0 & 0.0 & 0.0 \\
\hline \multirow[t]{2}{*}{ K3W5 } & 0.0 & 0.0 & 0.0 & 5.6 & 0.0 & 0.0 \\
\hline & ns & $\mathrm{ns}$ & ns & ns & $\mathrm{ns}$ & ns \\
\hline
\end{tabular}

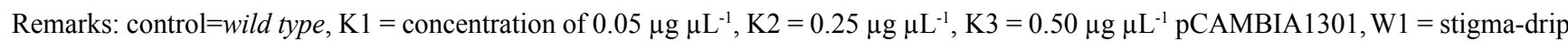
at $1 \mathrm{~h}, \mathrm{~W} 2=2 \mathrm{~h}, \mathrm{~W} 3=4 \mathrm{~h}, \mathrm{~W} 4=7 \mathrm{~h}, \mathrm{~W} 5=10 \mathrm{~h}$ after pollination, $\mathrm{ns}=$ non significant at $\alpha=0.05$

Chovelon et al. (2011) reported that $70-90 \%$ of explants expressed a transient GUS activity during the early stages of regeneration in melon transformation mediated by A. tumefaciens mediated, however, only 1.8-4.5\% transgenic plants were obtained. These results revealed a low capacity of melon GUS-positive cells to regenerate transgenic plants. Histological analyses indicated that genetic transformation occurred in epidermal and sub-epidermal cells and reached the meristematic structures expressing a high level of GUS activity during 14 days of culture; however after this period, most of the meristematic structures showed premature cell vacuolization and disorganization. This disruption of the GUS-positive meristematic areas could be responsible of the difficulties encountered to regenerate melon and other recalcitrant plants after genetic transformation.

\section{CONCLUSION}

The efficiency of transformation via pollen-tube pathway of three jatropha genotypes ranged from 1.5$16.7 \%$ based on histochemical and molecular analysis. Sequentially by PCR analysis with specific primers hptII and gus, transgenic plants obtained in 1-3 and 3-7 of the 15 combined treatments of concentration and application time of plasmid DNA. There are indications that the transformation efficiency via the pollen-tube pathway vary in each jatropha genotypes.

\section{ACKNOWLEDGEMENT}

We thank to the Directorate General of Higher Education, the Ministry of National Education of The Republic Indonesia for financial support through the BPPS (BPP-DN) and Center for Agricultural Biotechnology and Genetic Resources Research and Development for support material and molecular laboratory facilities.

\section{REFERENCES}

Bibi, N., K. Fan, S. Yuan, M. Ni, I.M. Ahmed, W. Malik, X. Wang. 2013. An efficient and highly reproducible approach for the selection of upland transgenic cotton produced by pollen tube pathway method. Aus. J. Crop. Sci. 7:1714-1722.

Chovelon, V., V. Restier, N. Giovinazzo, C. Dogimont, J. Aarrouf. 2011. Histological study of organogenesis in Cucumis melo L. after genetic transformation: why is it difficult to obtain transgenic plants?. Plant Cell Rep. 30:2001-2011.

Costa, G.G.L., K.C. Cardoso, L.E.V.D. Bem, A.C. Lima, M.A.S. Cunha, L. de Campos-Leite, R.Vicentini, F. Papes, R.C. Moreira, J.A. Yunes, F.A.P. Campos, M.J.D. Silva. 2010. Transcriptome analysis of the oil-rich seed of the bioenergy crop Jatropha curcas L. BMC Genomics 11:1-9. 
Dhakshanamoorthy, D., R. Selvaraj. 2009. Extraction of genomic dna from Jatropha sp. using modified CTAB method. Rom. J. Biol. Plant Biol. 54:117-125.

Djumali, E. Nurnasari. 2014. Plant characters that affected physic nut (Jatropha curcas L.) yield. J. Agron. Indonesia 42:66-73.

Gu, K., H. Mao, Z. Yin. 2014. Production of markerfree transgenic Jatropha curcas expressing hybrid Bacillus thuringiensis $\delta$-endotoxin Cry1Ab/1Ac for resistance to larvae of tortrix moth (Archips micaceanus). Biotech. Biofuels. 7:1-9.

Hao, J.F., Y.D. Niu, B.J. Yang. 2011. Transformation of a marker-free and vector-free antisense ACC oxidase gene cassette into melon via the pollen-tube pathway. Biotechnol. Lett. 33:55-61.

Jefferson, R.A. 1987. Assaying chimeric genes in plant: The gus gene fussion system. Plant Mol. Biol. Report. 5:387-405.

Joshi, M., A. Mishra, B. Jha. 2011. Efficient genetic transformation of Jatropha curcas L. by microprojectile bombardment using embryo axes. Indust. Crops Products. 33:67-77.

Keshamma, E., S. Rohini, K.S. Rao, B. Madhusudhan, M.U. Kumar. 2008. Tissue culture-independent in planta transformation strategy: An Agrobacterium tumefaciens-mediated gene transfer method to overcome recalcitrance in cotton (Gossypium hirsutum L.). J. Cotton Sci. 12:264-272.

Khemkladngoen, N., J. Cartagena, N. Shibagaki, K. Fukui. 2011a. Adventitious shoot regeneration from juvenile cotyledons of a biodiesel producing Plant, Jatropha curcas L. J. Biosci. Bioeng. 111:67-70.

Khemkladngoen, N., J. Cartagena, K. Fukui. 2011b. Physical wounding-assisted Agrobacterium-mediated transformation of juvenile cotyledons of a biodieselproducing plant, Jatrophacurcas L. Plant Biotech. Rep. 5:235-243.

Kumar, M., AK. Shukla, H. Singh, P.C. Verma, P.K. Singh. 2013. A genotype-independent agrobacteriummediated transformation of germinated embryo of cotton (Gossypium hirsutum L.). Int. J. Bio-Tech and Res. 3:81-90.

Kumar, N., K.G.V. Anand, D.V.N.S. Pamidimarri, T. Sarkar, M.P. Reddy, T. Radhakrishnan, T. Kaul, M.K. Reddy,
S.K. Sopori. 2010. Stable genetic transformation of Jatropha curcas via Agrobacterium tumefaciensmediated gene transfer using leaf explants. Indust. Crops Prod. 32:41-47.

Li, M., H. Li, H. Jiang, X. Pan, X. Wu. 2008. Establishment of an Agrobacterium-mediated cotyledone disc transformation method for Jatropha curcas. Plant Cell Tissue Organ Culture. 92:173-181.

Madhaiyan, M., T.H.H. Alex, S.T. Ngoh, B. Prithiviraj, L. Ji. 2015. Leaf-residing Methylobacterium species fix nitrogen and promote biomass and seed production in Jatropha curcas. Biotech. Biofuels. 8:1-14.

Noor, S., T. Husnain, S. Riazuddin. 2000. Screening for putative transgenic rice and cotton plants: A simple and easy method. Pak. J. Biol. Sci. 3:2226-2228.

Parwata, I.G.M.A., D. Indradewa, P. Yudono, B. D. Kertonegoro, R. Kusmarwiyah. 2014. Growth responses and yield of jatropha (Jatropha curcas L.) to drought stress under coastal sandy soil conditions in the first year of production cycle. J. Agron. Indonesia 42:59-65.

Shan, W., C. Zhao, J. Fan, H. Cong, S. Liang, X. Yu. 2012. Antisense suppression of alcohol acetyltransferase gene in ripening melon fruit alters volatile composition. Sci. Hort. 139:96-101.

Tsuchimoto, S., J. Cartagena, N. Khemkladngoen, S. Singkaravanit, T. Kohinata, N. Wada, H. Sakai, Y. Morishita, H. Suzuki, D. Shibata, K. Fukui. 2012. Development of transgenic plants in jatropha with drought tolerance. Plant Biotech. 29:137-143.

Wang, M., B. Zhang, Q. Wang. 2013. Cotton transformation via pollen tube pathway. p:71-77. In B. Zhang (Ed.), Transgenic cotton: Methods and Protocols, Methods in Molecular Biology. vol. 958. Springer Science Business Media, New York.

Zhang, H., F. Zhao, Y. Zhao, C. Guo, C. Li, K. Xiao. 2009. Establishment of transgenic cotton lines with high efficiency via pollen-tube pathway. Front. Agric. China 3:359-365.

Zhang, W., L. Jin, X. Li, X. Jiang, Y. Wang, X. Wang. 2012. Grain quality evaluations of hybrids between Triticum aestivum and Sorghum bicolor produced by pollen tube pathway method. Aust. J. Crop. Sci. 6:1712-1717. 